Journal of Engineering and Applied Sciences 14 (Special Issue 1): 3839-3841, 2019

ISSN: 1816-949X

(C) Medwell Journals, 2019

\title{
Study on Structural Behavior of Manufactured Sand in Concrete
}

\author{
K. Ayyappan and K. Thiruvenkatasamy \\ Department of Harbour and Ocean Engineering, AMET University, 135 East Coast Road, \\ Kanathur, 603112 Chennai, India
}

\begin{abstract}
Sand is a natural substance which is readily available in nature and it is used as an aggregate in the concrete mixture. But due to its increase in demand there is depletion of river sand and it became a scarce material. This research analyzes the feasibility of $M$-sand as an aggregate in concrete mix. M-sand means manufactured sand and is being prepared by crushing the rocks. In various percentages the river sand was replaced by M-sand and concrete mixes and sample were prepared. The compressive and flexural strength of these manufactured samples were analyzed with respect to the normal concrete mix.
\end{abstract}

Key words: Manufactured sand, M-sand, structural behavior, strength, concrete reinforcement, river

\section{INTRODUCTION}

River sand is a natural substance which is readily available in nature and it is used as an aggregate in the concrete mixture. Due to the continuous mining of sand from riverbed led to the depletion of river sand and it became a scarce material. Lowering of river beds and surface water are few environmental issues caused by the depletion of river sand due to continuous mining (Sureshbabu and Thomas, 2013).

A study was conducted by Reddy (2012) to ascertain the suitability of manufactured sand as fine aggregate in concrete (grades of M20, M30) and cement mortars (ratio 1:4 and 1:6). Tests were conducted to study fresh and hardened properties of the concrete and mortars made with river and manufactured sand. It was found that grading limits of manufactured sand fell within the grading Zone-II of fine aggregates as specified in IS 383. Shape of the manufactured sand particles resembled the shape of river sand particles. Bulk density and specific gravity of manufactured sand were comparable to those of river sand.

A study was conducted by Kode et al. (2007) on crushed stone dust as fine aggregate in structural concrete. It was $20.5 \mathrm{kNm}$ for sand beam and 18.94 $\mathrm{kNm}$ for stone crusher dust beam. Analyzing the test results it is concluded that stone crusher dust qualities itself as a suitable substitute for sand at very low cost.
An experiment for the influence of manufactured sand in Ferro cement elements was conducted by Sheela (2004). It is concluded that, the workability of manufactured sand specimens was low but the energy absorption capacity was more. The study indicate that manufactured sand or its combinations with river sand can be effectively used for the replacing the river sand. Use of manufactured sand in concrete and construction as an alternate to river sand is discussed by Sreenivasa (2012) and concluded that:

- Use of manufactured sand as alternative to river sand, reduce the impacts on environment

The construction industry shall start using the manufactured sand to full extent as alternative The Local Authorities/PWD/ Govt., shall encourage the use of manufactured sand in public construction works

- The govt. shall come out with policy on sand encourage the industry people to set up more no of sand crushing units across the all districts, states to meet the sand requirements of the construction industry

\section{MATERIALS AND METHODS}

River sand in concrete reinforcement are partially replaced with manufactured sand in different proportions such as 10,15 and $20 \%$. The physical and chemical properties of $\mathrm{M}$-sand are shown in

Corresponding Author: K. Ayyappan, Department of Harbour and Ocean Engineering, AMET University, 135 East Coast Road, Kanathur, 603112 Chennai, India 
Table 1: Chemical properties of M-sand

\begin{tabular}{ll}
\hline Descriptions & M-sand \\
\hline Sulphur trioxide & 72.6 \\
Potassium oxide & 0.45 \\
Sodium oxide & 0.23 \\
Magnesium oxide & 9.65 \\
Calcium oxide & 3.27 \\
Iron oxide & 13.66 \\
Alumina & 0.1 \\
Silica & - \\
Fineness \% passing $(45 \mu \mathrm{m})$ & 80 \\
Unit weight $\left(\mathrm{kg} / \mathrm{m}^{3}\right)$ & 2578 \\
S.gavity & 2.56 \\
\hline
\end{tabular}

Table 2: Physical property of M-sand

\begin{tabular}{ll}
\hline Descriptions & Values \\
\hline S. gravity & 2.56 \\
Fineness $(150 \mu \mathrm{m})$ & 99.45 \\
Fineness $(90 \mu \mathrm{m})$ & 98.01 \\
pH values & 10.28 \\
Color & Grayish white \\
\hline
\end{tabular}

Table 3: Test results compressive strength for cubes Compressive strength $\left(\mathrm{N} / \mathrm{mm}^{2}\right)$

\begin{tabular}{lllll} 
& & & \\
Number of & Conventional & M-sand concrete & \\
curing days & concrete & $10(\%)$ & $15(\%)$ & $20(\%)$ \\
\hline 7 & 21.05 & 24.44 & 24.78 & 26.55 \\
14 & 25.33 & 26.22 & 27.32 & 31.99 \\
28 & 32.57 & 41.02 & 42.30 & 43.66 \\
\hline
\end{tabular}

Table 4: Test results flexural strength for beams Fflexural strength $\left(\mathrm{N} / \mathrm{mm}^{2}\right)$

\begin{tabular}{lllll} 
& & M-sand concrete & \\
Number of & Conventional & - & \\
curing days & concrete & $10(\%)$ & $15(\%)$ & $20(\%)$ \\
\hline 7 & 3.46 & 2.87 & 2.58 & 3.50 \\
14 & 4.28 & 3.92 & 4.23 & 4.25 \\
28 & 5.86 & 5.16 & 6.33 & 6.77 \\
\hline
\end{tabular}

Table 1 and 2. Three different concrete mixes are prepared and in each mix 3 cubes and 3 beams are prepared and let free for upto maximum of 28 days. A cube and a beam from each sample are tested in the interval of 7,14 and 28 days. The compressive strength and flexural strength are measured for the samples and they are listed in Table 3 and 4.

\section{RESULTS AND DISCUSSION}

Compressive strength of cubes of different samples are shown in Table 3 and their comparison chart is show in Fig. 1. Tensile strength of beams of different samples are shown in Table 4 and their comparison chart is shown in Fig. 2. From table results we can say that, maximum compressive and flexural strength is achieved when there is $20 \%$ replacement of aggregates with $\mathrm{M}$-sand. So, the optimum percentage of replacement of M-sand is $20 \%$.

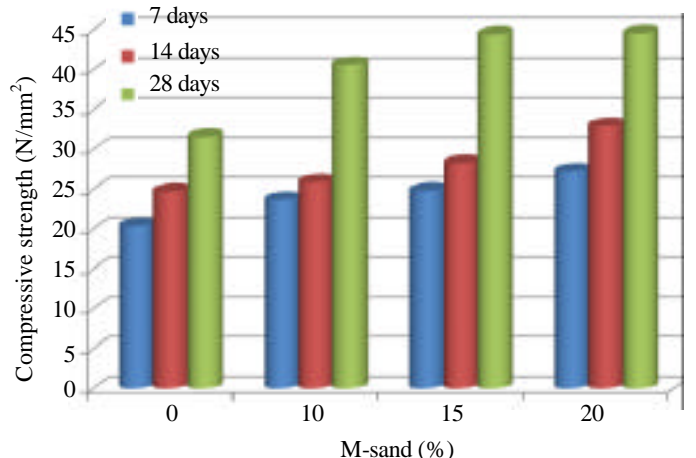

Fig. 1: Compressive strength of cubes

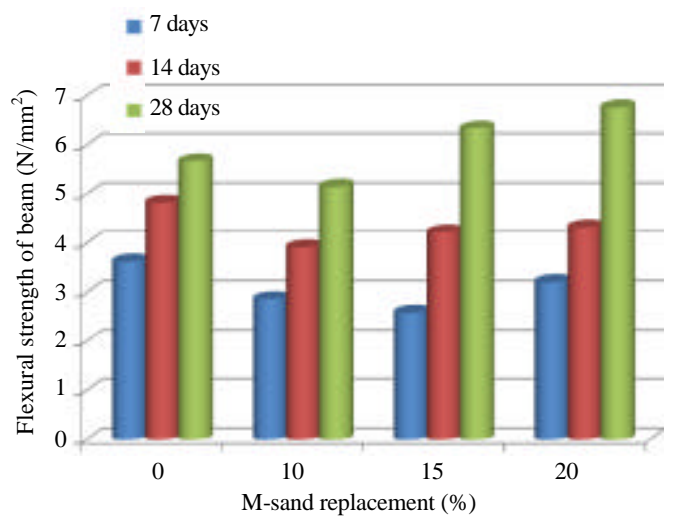

Fig. 2: Flexural strength of beams

\section{CONCLUSION}

The various percentage of $\mathrm{M}$-sand in concrete has the following conclusion. The maximum flexural strength for partial replacement of aggregates with $\mathrm{M}$-sand be achieved by $20 \%$ is found to be greater than the conventional concrete. It achieved maximum compressive strength when there is $20 \%$ replacement of aggregates with M-sand. So, the optimum percentage of replacement of M-sand is $20 \%$.

\section{REFERENCES}

Kode, V.R., D.S.R. Murty and P.S. Kumar, 2007. Appraisal of crushed stone dust, as fine aggregate in structural concrete. Civ. Eng. Constr. Rev., 20: 52-58.

Reddy, B.V.V., 2012. Suitability of manufactured sand (M-sand) as fine aggregates in mortars and concrete. Master Thesis, Department of Civil Engineering, Indian Institute of Science, Bangalore, Indian.

Sheela, S., 2004. Influence of M sand in ferrocement elements and its application. Indian Concr. J., 21: 187-223. 
Sreenivasa, G., 2012. Use of manufactured sand in concrete and construction an alternate to river sand. N B M Media Private Limited, New Delhi, India. https://www.nbmcw.com/tech-articles/concrete/286 75-use-of-manufactured-sand-in-concrete-and-cons truction-an-alternate-to-river-sand.html
Sureshbabu, N. and J. Thomas, 2013. Bond characteristic of rebar in concrete with manufactured sand as fine aggregate. Am. J. Eng. Res., 1: 54-58. 